\title{
Assessing ursolic acid contents of some commonly consumed herbs grown in Turkey
}

\author{
Türkiye'de yetişen ve yaygın olarak tüketilen bazı bitkilerin ursolik asit içeriklerinin \\ belirlenmesi
}

Oscar ZANNOU ${ }^{1, a}$, Burak İPEKCí1,b, İlkay KOCA ${ }^{1, c}$, Halil İbrahim ODABAŞ²,d

${ }^{1}$ Ondokuz Mayıs Üniversitesi, Mühendislik Fakültesi, Gıda Mühendisliği Bölümü, 55270, Samsun ${ }^{2}$ Gümüşhane Üniversitesi, Mühendislik ve Doğa Bilimleri Fakültesi, Gıda Mühendisliği Bölümü, 29100, Gümüşhane

• Geliş tarihi / Received: 03.05.2021 • Düzeltilerek geliş tarihi / Received in revised form: $25.11 .2021 \quad$ • Kabul tarihi / Accepted: 22.12 .2021

\begin{abstract}
Ursolic acid is a triterpenoid compound in the plant kingdom and has important biological functions. In this study, ursolic acid contents of nine herbs including Anethum graveolens (dill), Camellia sinensis L. (green tea), Lepidium sativum L. (garden cress), Ocimum basilicum L. (sweet basil), Petroselinum crispum L. (parsley), Rosmarinus officinalis L. (rosemary), Salvia officinalis L. (sage), Thymus vulgaris L. (thyme) and Urtica dioica L. (nettle) were determined by High-Performance Liquid Chromatography (RP-HPLC-UV). Based on the results from the analysis of herbs, ursolic acid contents varied between $0.20 \%$ and $7.11 \%$. The ursolic acid content was highest in rosemary and sage $(7.11 \pm 0.20 \%$ and $6.63 \pm 0.27 \%$, respectively), while the lowest content of ursolic acid was in nettle $(0.20 \pm 0.10)$. It is expected from the results of this work to contribute to the knowledge on the nutritional value of commonly consumed herbs in Turkey and encourage their consumption as functional foods.
\end{abstract}

Keywords: RP-HPLC-UV, Triterpene, Ursolic acid.

\section{$\ddot{O}_{z}$}

Ursolik asit, önemli biyolojik fonksiyonlara sahip olan ve bitkiler aleminde bulunan bir triterpenoid bileşiktir. Bu çalışmada, Anethum graveolens (dereotu), Camellia sinensis L. (yeşil çay), Lepidium sativum L. (tere), Ocimum basilicum L. (fesleğen), Petroselinum crispum L. (maydanoz), Rosmarinus officinalis L. (biberiye), Salvia officinalis L. (adaçayı), Thymus vulgaris L. (kekik) ve Urtica dioica L. (ısırgan)'i kapsayan 9 bitkinin Yüksek Performanslı Sivı Kromatografi (RP-HPLC-UV) ile ursolik asit içeriği belirlenmiştir. Bitkilerin ursolik asit içerikleri \%0.20 ile \%7.11 arasında

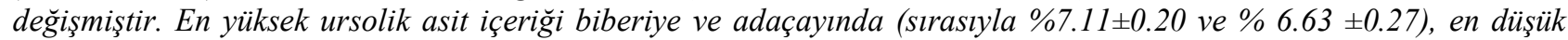

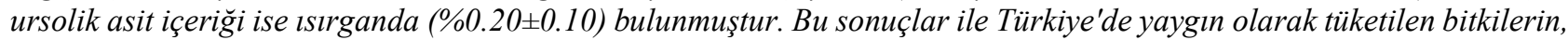
besleyici değerleri konusundaki bilgilere katkı sağlanılması ve bu bitkilerin fonksiyonel gıda olarak tüketilmelerinin teşvik edilmesi amaçlanmıştır.

Anahtarkelimeler: RP-HPLC-UV, Triterpen, Ursolik asit.

\footnotetext{
${ }^{*}$ Halil İbrahim ODABAŞ; hiodabas@gumushane.edu.tr, Tel: (0506) 545 34 25, orcid.org/0000-0001-7111-3852

${ }^{a}$ orcid.org/0000-0003-1227-1265 $\quad{ }^{\mathrm{b}}$ orcid.org/0000-0003-2793-2273 $\quad{ }^{\mathrm{c}}$ orcid.org/0000-0001-6089-8586
} 


\section{Introduction \\ 1. Giriş}

Pentacyclic triterpenoids are terpenes that have 30 carbons on their skeleton and are found in the food and herbs in form of free acid or aglycones for triterpenoid saponins. A wide range of these compounds have important pharmacological activities. Ursolic acid also known as $3 \beta$-hydroxyurs-12-en-28-oic-acid (UA) belongs to the ursane family. It is a natural pentacyclic triterpenoid carboxylic acid. UA is naturally found in the leaves and berries of natural medicinal plants and in the protective wax-like coatings of fruits. Recently, many studies have investigated the UA contents of some plants and fruits including. Both in vitro and in vivo studies have demonstrated that UA has biological functions including hepatoprotective, anti-inflammatory, anti-diabetic, anti-HIV, antimicrobial, anti-obesity, and anti-malarial activity (Cimanga et al., 2006; Ataie-Jafari et al., 2008; Jesus et al., 2015). Furthermore, it was found out that UA had marked anti-tumor effects and exhibited cytotoxic activity towards many cancer cell lines (Kim et al., 2011; Gai et al., 2016).

The UA contents of nine herbs such as Ocimum basilicum L., Lepidium sativum L., Anethum graveolens, Camellia sinensis L., Urtica dioica L., Petroselinum crispum L., Rosmarinu sofficinalis L. and Salvia officinalis L. were investigated in the present study. They are commonly consumed as traditional medicines, herbal teas, spices and vegetables. Their utilized parts, common uses, and biological activities are shown in Table 1. $O$. basilicum is cultivated worldwide for essential oil production and consumption for culinary purposes. L. sativum is commonly used as a salad ingredient in Anatolia. A. graveolens is generally used as a spice and employed in pickles, salads, sauces and soups. C. sinensis is one of the most consumed beverages thorough the world and a very important crop for local economy. It prevents catechin oxidation by polyphenoloxidase and provides many benefits to human health (Chan et al., 2011, Di Lorenzo et al., 2013). U. dioca is cultivated for the production of commercial chlorophyll used as a green food colorant. P. crispum is an aromatic and medicinal commonly used seasoning and flavoring agent for meat and sausages. $R$. officinalis is commonly used as traditional medicine and flavouring food products in Anatolia. S. officinalis is commonly used in culinary and as herbal tea in Anatolia. Likewise, T. vulgaris is generally used as a medicinal herb, herbal tea and flavouring agent.

The UA extraction technique is a determinant factor that affect the UA extraction yield. Several methods including maceration, heat reflux extraction, soxhlet, accelerated solvent extraction, microwave-assisted extraction, subcritical water and ultrasound-assisted extraction have been tested for the extraction of pentacyclic triterpenoids (Mlyuka et al., 2016; Bernatoniene et al., 2016). These authors stated that ultrasound-assisted extraction is more efficient method, easy to use, and more economical. The ultrasound-assisted extraction enhances the extraction efficiency thanks to the disruption of cell walls and reduction of particle size, enhancing the mass transfer of the cell contents as the result of cavitation bubble collapse. Furthermore, for the qualitative and quantitative analysis, high performance liquid chromatography (RP-HPLC) was revealed to be the most suitable method for the separation and quantification of UA.

To the best knowledge of the authors, no study has reported the UA content of $A$. graveolens, $C$. sinensis, $L$. sativum, $P$. crispum, $R$. officinalis, $S$. officinalis, $O$. basilicum, $U$. dioca and T. vulgaris grown in Turkey. Therefore, the present study aimed to evaluate for the first time the UA contents of Turkish A. graveolens, C. sinensis, L. sativum, $P$. crispum, $R$. officinalis, $S$. officinalis, $O$. basilicum, $U$. dioca and T. vulgaris. For this purpose, the ultrasound-assisted extraction was used for UA extraction and RP-HPLC-UV was employed for the qualitative and quantitative evaluations. 
Table 1. Utilized parts, popular use and biological activities of herbs used in this study

Tablo 1. Çalışmada kullanılan bitkilerin yararlanılan kısımları, popüler kullanım şekilleri ve biyolojik aktiviteleri.

\begin{tabular}{|c|c|c|c|c|c|}
\hline $\begin{array}{l}\text { Binominal } \\
\text { name }\end{array}$ & $\begin{array}{l}\text { Common } \\
\text { names }\end{array}$ & $\begin{array}{l}\text { Edible } \\
\text { parts }\end{array}$ & $\begin{array}{l}\text { Popular } \\
\text { use }\end{array}$ & $\begin{array}{l}\text { Biological activities and role in } \\
\text { traditional medicine }\end{array}$ & References \\
\hline $\begin{array}{l}\text { Ocimum } \\
\text { basilicum L. }\end{array}$ & $\begin{array}{l}\text { Sweet } \\
\text { basil }\end{array}$ & $\begin{array}{l}\text { Fresh } \\
\text { leaves } \\
\text { Seeds }\end{array}$ & $\begin{array}{l}\text { Vegetable } \\
\text { Herbal tea } \\
\text { Spice }\end{array}$ & $\begin{array}{l}\text { Treatment of cough, inflammations, } \\
\text { constipation, dyspepsia, diarrhea, aches, } \\
\text { warts, worms, kidney malfunctions and } \\
\text { pains. }\end{array}$ & $\begin{array}{l}\text { Opalchenova } \\
\text { and } \\
\text { Obreshkova, } \\
2003\end{array}$ \\
\hline $\begin{array}{l}\text { Lepidium } \\
\text { sativum } \mathrm{L} .\end{array}$ & $\begin{array}{l}\text { Garden } \\
\text { cress }\end{array}$ & $\begin{array}{l}\text { Fresh } \\
\text { leaves } \\
\text { Seeds }\end{array}$ & Vegetable & $\begin{array}{l}\text { Treatment of asthma, bronchitis cough, } \\
\text { hypertension, and renal disease. } \\
\text { Antibacterial, aphrodisiac, diuretic, } \\
\text { expectorant, gastrointestinal stimulant, } \\
\text { gastroprotective, laxative, stomachic and } \\
\text { diuretic agent. }\end{array}$ & $\begin{array}{l}\text { Rehman et al., } \\
2012\end{array}$ \\
\hline $\begin{array}{l}\text { Anethum } \\
\text { graveolens }\end{array}$ & Dill & $\begin{array}{l}\text { Fresh } \\
\text { leaves } \\
\text { Seeds } \\
\text { Stems }\end{array}$ & Vegetable & $\begin{array}{l}\text { Treatment of stomachache, indigestion, } \\
\text { flatulence, gripe, hiccups and colic. } \\
\text { Antihyperlipidaemic, } \\
\text { antihypercholesterolaemic, anticancer, } \\
\text { antidiabetic, antioxidant and diuretic. }\end{array}$ & $\begin{array}{l}\text { Kaur and } \\
\text { Arora, } 2010\end{array}$ \\
\hline $\begin{array}{l}\text { Camellia } \\
\text { sinensis L. }\end{array}$ & Green tea & $\begin{array}{l}\text { Dried } \\
\text { leaves }\end{array}$ & Herbal tea & $\begin{array}{l}\text { Reduction of the risk of cancer, } \\
\text { cardiovascular diesases, ischemic damage } \\
\text { and neurodegenerative diseases. } \\
\text { Antioxidant, antidiabetic, antibacterial, } \\
\text { anti-inflammatory and anti-HIV activities. }\end{array}$ & $\begin{array}{l}\text { Chopade et al., } \\
2008\end{array}$ \\
\hline $\begin{array}{l}\text { Urtica dioica } \\
\text { L. }\end{array}$ & Nettle & $\begin{array}{l}\text { Fresh } \\
\text { leaves }\end{array}$ & $\begin{array}{l}\text { Vegetable } \\
\text { Herbal tea }\end{array}$ & $\begin{array}{l}\text { Good for anemia, diabetes, rheumatism, } \\
\text { eczema, diarrhea, prostatic hyperplasia. } \\
\text { Antimicrobial, antiulcer, analgesic effects. }\end{array}$ & $\begin{array}{l}\text { Akbay et al., } \\
\text { 2003; Gülçin et } \\
\text { al., } 2004\end{array}$ \\
\hline $\begin{array}{l}\text { Petroselinum } \\
\text { crispum L. }\end{array}$ & Parsley & $\begin{array}{l}\text { Fresh } \\
\text { leaves }\end{array}$ & Vegetable & $\begin{array}{l}\text { Uses as a stomachic, carminative, } \\
\text { emmenagogue, abortifacient, and diuretic } \\
\text { agent. }\end{array}$ & $\begin{array}{l}\text { Kreydiyyeh and } \\
\text { Usta, } 2002\end{array}$ \\
\hline $\begin{array}{l}\text { Rosmarinus } \\
\text { officinalis L. }\end{array}$ & Rosemary & $\begin{array}{l}\text { Dried } \\
\text { or fresh } \\
\text { leaves }\end{array}$ & Spice & $\begin{array}{l}\text { Antibacterial, antioxidant, and } \\
\text { antimutagenic effects. Treatment of } \\
\text { diabetes, respiratory disorders, stomach } \\
\text { problems and inflammatory diseases. }\end{array}$ & $\begin{array}{l}\text { Oluwatuyi et } \\
\text { al., 2004; } \\
\text { Bakirel et al., } \\
2008\end{array}$ \\
\hline $\begin{array}{l}\text { Salvia } \\
\text { officinalis L. }\end{array}$ & Sage & $\begin{array}{l}\text { Dried } \\
\text { or fresh } \\
\text { leaves }\end{array}$ & $\begin{array}{l}\text { Spice } \\
\text { Herbal tea }\end{array}$ & $\begin{array}{l}\text { Anti-inflammatory, antidiarrheal, } \\
\text { antiseptic, digestive, diuretic, expectorant, } \\
\text { hemostatic, laxative, sedative, spasmolytic } \\
\text { and hypoglycemic properties. }\end{array}$ & $\begin{array}{l}\text { Gali-Muhtasib, } \\
2006\end{array}$ \\
\hline
\end{tabular}

\section{Material and methods}

2. Materyal ve metot

\subsection{Materials}

\subsection{Materyaller}

The herbs used in this study were shown in Table 1 The herbs were collected from different locations in Turkey. L. sativum, A. graveolens and $P$. crispum were harvested from Rize province. $O$. basilicum, $C$. sinensis, $U$. dioca, $R$. officinalis $S$. officinalis and T. vulgaris samples were collected from Mersin province. The fresh samples were dried in a vacuum oven at $60{ }^{\circ} \mathrm{C}$ for 8 hours. All samples were ground into powder with a coffee mill, and stored at $+4^{\circ} \mathrm{C}$ until analyses.

All reagents and solvents were analytical grade. UA (98\%) was purchased from Sigma-Aldrich Co. (Milwaukee, Wisconsin, USA).

\subsection{Methods \\ 2.2. Metotlar}

\subsubsection{Dry matter content \\ 2.2.1. Kuru madde miktarl}

Dry matter content was determined by drying the samples in the oven at $105{ }^{\circ} \mathrm{C}$ until to constant weight (AOAC, 2000).

\subsubsection{Extraction of ursolic acid \\ 2.2.2. Ursolik asit ekstraksiyonu}

The extraction of ursolic acid was carried out adopting the method described in Wójciak-Kosior et al. (2013) with some modifications. Briefly, a portion of the powder $(5 \mathrm{~g})$ of the samples was accurately weighed, and placed in a capped glass tube, and then mixed with $100 \mathrm{~mL}$ of methanol. 
The mixtures were kept for $30 \mathrm{~min}$ to allow the solvent to wet the samples and the tubes were subjected to the sonication in an ultrasonic bath (WiseClean WUC-A02H, Daihan Scientific Co., Gangwon-do, Korea) at $48 \pm 2^{\circ} \mathrm{C}$ for $120 \mathrm{~min}$. The extracts were appropriately diluted and then passed through a $0.45 \mu \mathrm{m}$ membrane filter (Pall Ultipor ${ }^{\circledR}$ N66) for RP-HPLC-UV analysis.

\subsubsection{Determination of ursolic acid by RP- HPLC-UV}

2.2.3. Ursolik asit miktarını RHPLC-UV ile belirlenmesi

Analysis of UA was done by RP-HPLC (Series 200, PerkinElmer Inc., Massachusetts, USA) equipped with a pump, an autosampler, and a UVVIS detector. Separation was carried out by using a $150 \times 4.6 \mathrm{~mm}, 5 \mu \mathrm{m}$ Inertsil ${ }^{\circledR}$ ODS-4 C18 column. RP-HPLC analysis for UA was carried out according to the method described by Taralkar and Chattopadhyay (2012). The mobile phase consisted of a mixture, acetonitrile: methanol (80:20, v/v). The solution was degassed in an ultrasound bath and filtered under vacuum through a membrane (Immobilon ${ }^{\circledR}$-P PVDF). The flow was $0.5 \mathrm{~mL} \mathrm{~min}^{-}$ 1. The column temperature was maintained at $35 \pm 0.2^{\circ} \mathrm{C}$. The effluent was measured at a wavelength of $210 \mathrm{~nm}$ for the detection of UA. To prepare standard solutions, $10.0 \mathrm{mg}$ of UA standard was accurately weighted and dissolved in methanol (10 mL). Volumes of $0.25,0.5,1.0,2.0,4.0,8.0$, $10 \mathrm{~mL}$ of UA standard solution were placed in 100 $\mathrm{mL}$ volumetric flasks and methanol added to a final volume of $100 \mathrm{~mL}$. The solutions were filtered through a $0.45 \mu \mathrm{m}$ membrane filter and analyzed in RP-HPLC. $10 \mu \mathrm{L}$ of each solution were injected three times. Identification of UA was made by the comparison of the retention times with those of standard (Figure 1). The retention time for UA is $8.43 \mathrm{~min}( \pm 0.2 \mathrm{~min})$. The area under the peak of the UA vs. concentration plot showed a linear fit with a correlation coefficient of 0.999 . Quantification was performed on the basis of a linear calibration plot of peak area against concentration. Limit of detection (LOD) and limit of quantification (LOQ) were calculated as 1.667 and 5.003 ppm, respectively.

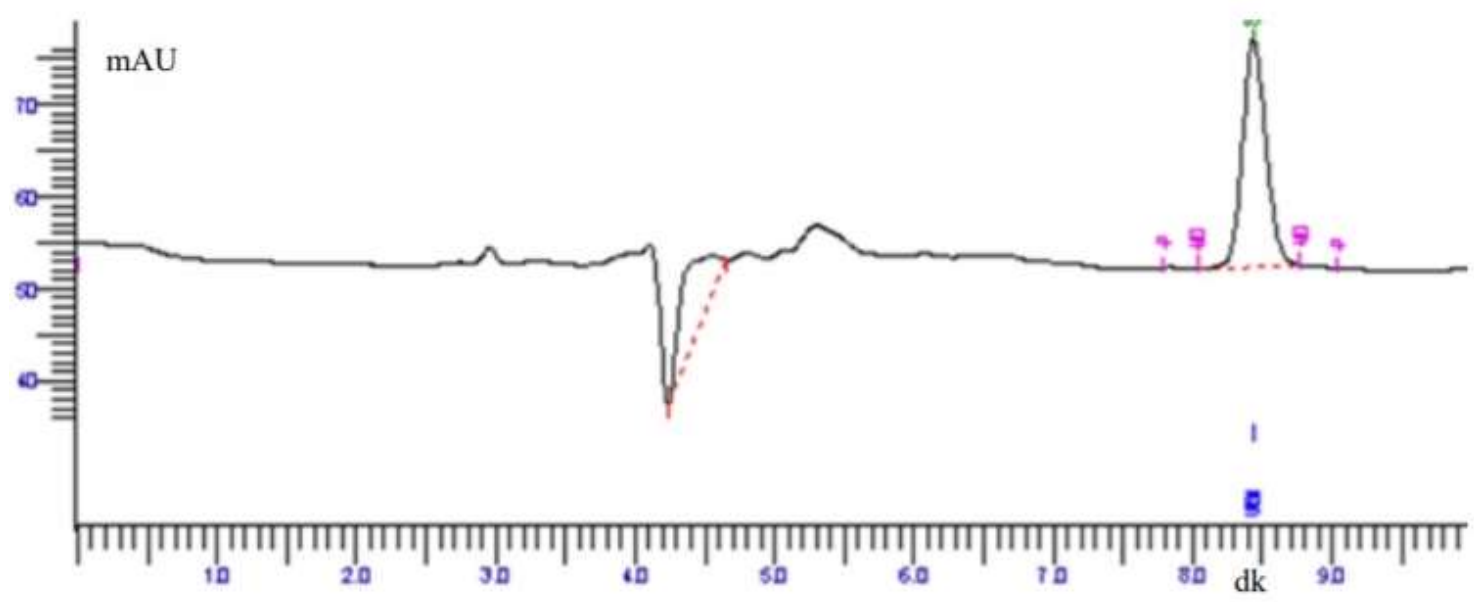

Figure 1. RP-HPLC chromatogram of the standard UA Şekil 1. UA standardinin RP-HPLC kromatogramı

\subsubsection{Statistical analysis}

\subsubsection{Istatistiksel analizler}

The results are shown as means \pm standard deviation. Statistical significance $(p<0.05)$ was measured by one-way ANOVA, followed by Duncan's multiple comparison test.

\section{Results and discussion}

3. Bulgular ve tartışma

The UA contents of the studied herb samples were given in Table 2. The averages of UA contents in the samples were $7.11 \%, 6.63 \%, 2.41 \%, 1.47 \%$,
$0.92 \%, 0.56 \%, 0.50 \%, 0.47 \%$ and $0.20 \%$ dry weight basis for $R$. officinalis, $L$. sativum, $A$. graveolens, $P$. crispum, O. basilicum, L. sativum, $C$. sinensis, $T$. vulgaris and $U$. dioica, respectively. As can be seen, the UA contents of the samples were ranged between $0.20 \%$ and $7.11 \%$. WójciakKosior et al. (2013) reported UA amounts ranged from 39.1 to $67.3 \mu \mathrm{g} / \mathrm{g}$ (from 0.00391 to $0.00673 \%$ ) in L. albi flos, while Al-Tannak and Novotny (2020) found out that the UA content corresponded to $25.57 \mu \mathrm{g} / \mathrm{g}(0.002557 \%), 28.70$ $\mu \mathrm{g} / \mathrm{g}(0.00287 \%)$ and $55.10 \mu \mathrm{g} / \mathrm{g}(0.00551 \%)$ in oregano (Al-Baraka), oregano (Waitro's) and olive leaves, respectively. Likewise, Rubashvili et al. 
(2020) mentioned a UA content of 2.412-4.585 $\mathrm{mg} / \mathrm{g}(0.2412-0.4585 \%)$ in apple waste. Meng et al. (2019) applied the single factor experimental design to maximize the extraction of UA from Paulownia flos. They reported that the UA content of Paulownia flos varied from 0.978 to $1.319 \mathrm{mg} / \mathrm{g}$ dry weight corresponding to $0.0978-0.1319 \%$ dry weight. The extraction of UA from different parts of G. hederacea and G. hirsuta yielded 2.73$25.15 \%$ and $3.47-26.82 \%$, respectively (Grabowska et al., 2021). When comparing our findings to these previous studies, it can be assumed that although the extraction techniques and solvents are determinant factors for the extraction of UA, the Turkish $R$. officinalis, $L$. sativum, A. graveolens, $P$. crispum, $O$. basilicum, L. sativum, $C$. sinensis, $T$. vulgaris and $U$. dioica can be considered as rich sources of UA. The highest value was in found $R$. officinalis (mean $7.11 \%$ ) followed by the L. sativum (mean $6.63 \%$ ). The lowest amounts of UA are found nettle (mean $0.20 \%$ ). R. officinalis and L. sativum can be regarded as rich sources of UA, since they displayed a higher amount of UA and are generally consumed raw in salads. Razboršek et al. (2007) determined the UA contents of $1.89 \mathrm{mg} / \mathrm{g}$ and 4.15 $\mathrm{mg} / \mathrm{g}$ in dry weight in $R$. officinalis and $S$. officinalis was, respectively, while, Jäger et al. (2009) reported a maximum concentration of $2.95 \%$ of UA in dry $R$. officinalis leaves. Janicsák et al. (2006) found that the UA content was $3.825 \%$ in S. officinalis. Comparing the previous findings to our data, it can be assumed that UA contents in $R$. officinalis and L. sativum studied in the represent work are at least two-fold higher than those reported previously.

Table 2. Ursolic acid contents of herbs used in this study.

Tablo 2. Çalışmada kullanılan bitkilerin ursolik asit içerikleri.

\begin{tabular}{llll}
\hline Common name & Binominal name & Ursolic acid (\%) & Mean \pm std \\
\hline Dill & Anethum graveolens & $0.96-3.43$ & $2.41 \pm 0.98 \mathrm{~b}$ \\
Garden cress & Lepidium sativum L. & $0.35-0.93$ & $0.56 \pm 0.23 \mathrm{de}$ \\
Green tea & Camellia sinensis L. & $0.47-0.55$ & $0.50 \pm 0.04 \mathrm{de}$ \\
Nettle & Urtica dioica L. & $0.13-0.37$ & $0.20 \pm 0.10 \mathrm{e}$ \\
Parsley & Petroselinum crispum L. & $1.26-1.64$ & $1.47 \pm 0.18 \mathrm{c}$ \\
Rosemary & Rosmarinus officinalis L. & $6.86-7.28$ & $7.11 \pm 0.20 \mathrm{a}$ \\
Sage & Salvia officinalis L. & $6.26-6.97$ & $6.63 \pm 0.27 \mathrm{a}$ \\
Sweetbasil & Ocimum basilicum L. & $0.67-1.37$ & $0.92 \pm 0.32 \mathrm{~d}$ \\
Thyme & Thymus vulgaris L. & $0.43-0.54$ & $0.47 \pm 0.04 \mathrm{de}$ \\
\hline
\end{tabular}

The different letters in the same column denote the significant differences $(\mathrm{p}<0.05)$.

UA contents of $A$. graveolens and $P$. crispum were reported for the first and their values were found lower than those of $R$. officinalis and L. sativum. $C$. sinensis and L. sativum displayed low UA content of $0.50 \%$ and $0.56 \%$ dry weight, respectively, and could be considered as poor UA sources. Regarding $O$. basilicum, our result is in accordance with Silva et al. (2008) who have determined $0.27 \%$ dry weight of UA in $O$. basilicum and $2.02 \%$ dry weight in $O$. tenuiflorum. In contrast, Jäger et al. (2009) have reported a higher value of UA in $T$. vulgaris when compared to our result. The lowest amount of UA found in $U$. dioica is consistent with Shailajan et al. (2014) who have mentioned low UA content ranged from 0.125 and $0.14 \mathrm{mg} / \mathrm{g}$. Similarly, Bourgeois et al. (2016) have applied an optimization design to optimize the extraction conditions of UA from $U$. dioica and determined low amount of UA ranged from 0.99 to $32.41 \mu \mathrm{g} / \mathrm{g}$ dry weight in $U$. dioica having anti-aging and antioxidant activity. These differences may be due to the extraction methods, analysis methods, geographical origins, growing season, and agricultural practices.

\section{Conclusion \\ 4. Sonuç}

In this study, UA contents of herbs that are generally used as raw (parsley, dill and cress), herbal tea or spices (rosemary, nettle, sage, thyme, sweet basil and green tea) in Turkey have been determined. The UA content was highest in rosemary and sage $(7.11 \pm 0.20 \%$ and $6.63 \pm 0.27 \%$, respectively), while the lowest content of UA was in nettle $(0.20 \pm 0.10)$. In general, the UA content of herbs grown in Turkey was higher than that reported by many researchers. It has been shown that ultrasound-assisted extraction is an effective method for the recovery of UA from herbs. UA and its esters are virtually insoluble in water, thus, their bioavailability in the body is limited. Therefore, the 
use of these herbs as fresh or spice instead of consuming as herbal tea may help to increase the bioavailability of UA. Further studies should be done on the bioavailability of UA in these herbs.

\section{Author contribution}

Yazar katkısı

Oscar Zannou: Writing- Original draft, Burak İpekci: Visualization, Investigation, İlkay Koca: Conceptualization, Supervision, Halil İbrahim Odabaş: Writing- Original draft, WritingReviewing and Editing.

\section{Declaration of ethical code Etik beyan}

The author(s) of this article declares that the materials and methods used in this study do not require ethical committee permission and/or legalspecial permission.

\section{Conflicts of interest \\ Çıkar çatışması beyanı}

The authors declare that they have no conflict of interest

\section{References}

Kaynaklar

Akbay, P., Basaran, A.A., Undeger, U. \& Basaran, N. (2003). In vitro immunomodulatory activity of flavonoid glycosides from Urtica dioica L". Phytotherapy Research, 17(1), 34-37. https://doi.org/10.1002/ptr.1068

Al-Tannak, N. F. \& Novotny, L. (2020). LC-MS method for the detection and quantification of ursolic acid and uvaol levels in olive leaves and oregano. Emirates Journal of Food and Agriculture, $32(8)$, 600-609 https://doi.org/10.9755/ejfa.2020.v32.i8.2137

AOAC (2000). Official methods of analysis of AOAC International, Gaithersburg, Md., Association of Official Analytical Chemists. https://doi.org/10.1002/jps.2600700437

Ataie-Jafari, A., Hosseini, S., Karimi, F. \& Pajouhi, M. (2008). Effects of sour cherry juice on blood glucose and some cardiovascular risk factors improvements in diabetic women: A pilot study. Nutrition and Food Science, 38(4), 355360.

https://doi.org/10.1108/00346650810891414

Bakırel, T., Bakırel, U., Keleş, O. Ü., Ülgen, S. G. \& Yardibi, H. (2008). In vivo assessment of antidiabetic and antioxidant activities of rosemary (Rosmarinus officinalis) in alloxan- diabetic rabbits. Journal of ethnopharmacology, 116(1),64-73.

https://doi.org/10.1016/j.jep.2007.10.039

Bernatoniene, J., Cizauska1te, U., Ivanauskas, L., Jakstas, V., Kalveniene, Z. \& Kopustinskiene, D. M. (2016). Novel approaches to optimize extraction processes of ursolic, oleanolic and rosmarinic acids from Rosmarinus officinalis leaves. Industrial Crops and Products, 84, 72-79. https://doi.org/10.1016/j.indcrop.2016.01.031

Bourgeois, C., Leclerc, E.A., Corbin, C., Dossout, J., Serrano, V., Vanier, J-R., Seigneuret, J-M., Auguin, D., Pichon, C., Lainé, E. \& Hano, C. (2016). Nettle (Urtica dioica) as source of antioxidant and anti-ageing for cosmetic applications. Comptes rendus Chimie, 19(9), 1090-1100. https://doi.org/10.1016/j.crci.2016.03.019

Chan, E. W. C., Soh, E.Y., Tie, P.P. \& Law, Y.P. (2011). Antioxidant and antibacterial properties of green, black, and herbal teas of Camellia sinensis. Pharmacognosy Research, 3(4), 266-272. https://doi.org/10.4103/0974-8490.89748

Chopade, V., Phatak, A., Upaganlawar, A. \& Tankar, A. (2008), Green tea (Camellia sinensis): Chemistry, traditional, medicinal uses and its pharmacological activities-a review. Pharmacognosy Reviews, 2(3),157-162

Cimanga, R. K., Tona, G.L., Mesia, G.K., Kambu, O.K., Bakana, D.P., Kalenda, P.D.T., Penge, A.O., Muyembe, J.-J.T., Totté, J., Pieters, L. \& Vlietinck, A. J. (2006). Bioassay-Guided isolation of antimalarial triterpenoid acids from the leaves of Morinda lucida. Pharmaceutical Biology, 44(9), 677-681. https://doi.org/10.1080/13880200601009123

Di Lorenzo, C., Dell'Agli, M., Sangiovanni, E., Dos Santos, A., Uberti, F., Moro, E., Bosisio, E. \& Restani, P. (2013). Correlation between catechin content and nf- $\kappa b$ inhibition by infusions of green and black tea. Plant Foods for Human Nutrition, 68(2), 149-154. https://doi.org/10.1007/s11130013-0354-0

Gai, W. T., Yu, D.P., Wang, X.S. \& Wang, P.T. (2016). Anti-cancer effect of ursolic acid activates apoptosis through ROCK/PTEN mediated mitochondrial translocation of cofilin-1 in prostate cancer. Oncology Letters, 12(4), 28802885. https://doi.org/10.3892/ol.2016.5015

Gali-Muhtasib, H. (2006). Anticancer and medicinal properties of essential oil and extracts of East Mediterranean sage (salvia triloba), Mahmud, T. H. K. and Arjumand, A. (Eds.), Advances in Phytomedicine, (Vol. 2, pp. 169-180). Elsevier. 
Grabowska, K., Żmudzki, P., Wróbel-Biedrawa, D., \& Podolak, I. (2021). Simultaneous quantification of ursolic and oleanolic acids in Glechoma hederacea and Glechoma hirsuta by UPLC/MS/MS. Planta Medica, 87(04), 305313. https://doi.org/10.1055/a-1345-9377

Gülçin, I., Küfrevioğlu, Ö.İ., Oktay, M. \& Büyükokuroğlu, M.E. (2004). Antioxidant, antimicrobial, antiulcer and analgesic activities of nettle (Urtica dioica L.). Journal of Ethnopharmacology, 90(2), 205-215. https://doi.org/10.1016/j.jep.2003.09.028

Jäger, S., Trojan, H., Kopp, T., Laszczyk, M.N. \& Scheffler, A. (2009). Pentacyclic triterpene distribution in various plants-rich sources for a new group of multi-potent plant extracts. Molecules, 14(6), 2016-2031. https://doi.org/10.3390/molecules14062016

Janicsák, G., Veres, K., Kakasy, A.Z. \& Máthé, I. (2006). Study of the oleanolic and ursolic acid contents of some species of the Lamiaceae.Biochemical Systematics and Ecology, 34(5), 392-396. https://doi.org/10.1016/j.bse.2005.12.004

Jesus, J.A., Lago, J.H.G., Laurenti, M.D., Yamamoto, E.S. \& Passero, L. F. D. (2015). Antimicrobial activity of oleanolic and ursolic acids: An update. Evidence-based Complementary and Alternative Medicine, 620472,1-14. https://doi.org/10.1155/2015/620472

Kaur, G.J., \& Arora, D.S. (2010). Bioactive potential of Anethum graveolens, Foeniculum vulgare and Trachyspermum ammi belonging to the family Umbelliferae-Current status. Journal of Medicinal Plants Research, 4(2), 087-094. https://doi.org/10.5897/JMPR09.018

Kim, K.H., Seo, H.S., Choi, H.S., Choi, I.H., Shin, Y.C. \& Ko, S.G. (2011). Induction of apoptotic cell death by ursolic acid through mitochondrial death pathway and extrinsic death receptor pathway in MDA-MB-231 cells. Archives of Pharmacal Research, 34(8), 1363-1372. https://doi.org/10.1007/s12272-011-0817-5

Kreydiyyeh, S.I. \& Usta, J. (2002). Diuretic effect and mechanism of action of parsley. Journal of Ethnopharmacology, $\quad$ 79(3) 353-357. https://doi.org/10.1016/S0378-8741(01)00408-1

Meng, X., Liu, D., Yang, M., Shi, Y. \& He, H. (2019). Establishment of extraction design space for ursolic acid from Paulowniae Flos based on the concept of quality by design. Phytochemical Analysis, 31(5), 535-544. https://doi.org/10.1002/pca.2892

Mlyuka, E., Zhang, S., Wang, L., Zheng, Z. \& Chen, J. (2016). Characteristics of subcritical water extraction and kinetics of pentacyclic triterpenoids from dry loquat (Eriobotrya japonica) leaves. International Journal of Food Engineering, 12(6), 547-555. https://doi.org/10.1515/ijfe-2016-0054

Oluwatuyi, M., Kaatz, G.W. \& Gibbons, S. (2004). Antibacterial and resistance modifying activity of Rosmarinus officinalis. Phytochemistry, 65(24), 3249-3254. https://doi.org/10.1016/j.phytochem.2004.10.00 9

Opalchenova, G. \& Obreshkova, D. (2003). Comparative studies on the activity of basil-an essential oil from Ocimum basilicum L. - against multidrug resistant clinical isolates of the genera Staphylococcus, Enterococcus and Pseudomonas by using different test methods. Journal of Microbiological Methods, 54(1), 105-110. https://doi.org/10.1016/S0167-7012(03)00012-5

Razboršek, M.I., Vončina, D.B., Doleček, V. \& Vončina, E. (2007). Determination of major phenolic acids, phenolic diterpenes and triterpenes in rosemary (Rosmarinus officinalis L.) by gas chromatography and mass spectrometry. Acta Chimica Slovenica, 54(1), 60-67.

Rehman, N. U., Khan, A. U., Alkharfy, K. M. \& Gilani, A. H. (2012). Pharmacological basis for the medicinal use of Lepidium sativum in airways disorders. Evidence-Based Complementary and Alternative Medicine. 596524, 1-8, https://doi.org/10.1155/2012/596524

Rubashvili, I., Tsitsagi, M., Zautashvili, M., Chkhaidze, M., Ebralidze, K. \& Tsitsishvili, V. (2020). Extraction and analysis of oleanolic acid and ursolic acid from apple processing waste materials using ultrasound-assisted extraction technique combined with high performance liquid chromatography. Revue Roumaine de Chimie, 65(10), 919-928. https://doi.org/10.33224/rrch.2020.65.10.07

Silva M.G.V., Vieira Í.G.P., Mendes F.N.P., Albuquerque, I.L., Dos Santos R.N., Silva F.O. \& Morais S.M. (2008). Variation of ursolic acid content in eight ocimum species from northeastern Brazil. Molecules, 13(10), 24822487.

https://doi.org/10.3390/molecules13102482

Shailajan, S., Hande, H., Singh D. \& Tiwari, B. (2014). Estimation of ursolic acid from Urtica dioica $\mathrm{L}$. using validated HPTLC method. Journal of Applied Pharmaceutical Science, 4(5), 092-095. https://doi.org/10.7324/japs.2014.40517

Taralkar, S. V. \& Chattopadhyay, S. (2012). A HPLC Method for determination of ursolic acid and betulinic acids from their methanolic extracts of 
Vitex Negundo Linn. Journal of analytical and bioanalytical Techniques, 3(3), 1-6. https://doi.org/10.4172/2155-9872.1000134

Wójciak-Kosior, M., Sowa, I., Kocjan, R., \& Nowak, R. (2013). Effect of different extraction techniques on quantification of oleanolic and ursolic acid in
Lamii albi flos. Industrial Crops and Products,

44,

$373-$

377. https://doi.org/10.1016/j.indcrop.2012.11.0 18 